\title{
Isotopic and Water Relation Responses to Ozone and Water Stress in Seedlings of Three Oak Species with Different Adaptation Strategies
}

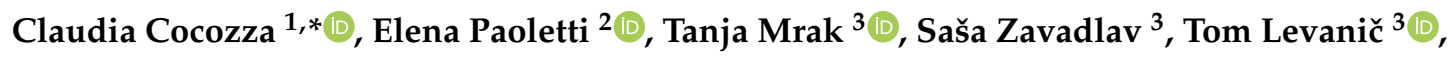 \\ Hojka Kraigher ${ }^{3}$, Alessio Giovannelli ${ }^{2}$ (D) and Yasutomo Hoshika ${ }^{2}$ (D) \\ 1 Department of Agriculture, Food, Environment and Forestry, University of Florence, Via San Bonaventura \\ 13, 50121 Florence, Italy \\ 2 Institute of Research on Terrestrial Ecosystems (IRET), National Research Council (CNR), Via Madonna del \\ Piano 10, 50019 Sesto Fiorentino, Italy; elena.paoletti@cnr.it (E.P.); alessio.giovannelli@cnr.it (A.G.); \\ yasutomo.hoshika@cnr.it (Y.H.) \\ 3 Slovenian Forestry Institute, Večna pot 2, 1000 Ljubljana, Slovenia; tanja.mrak@gozdis.si (T.M.); \\ sasa.zavadlav@gmail.com (S.Z.); tom.levanic@gozdis.si (T.L.); hojka.kraigher@gozdis.si (H.K.) \\ * Correspondence: claudia.cocozza@unifi.it
}

Received: 27 June 2020; Accepted: 6 August 2020; Published: 8 August 2020

\begin{abstract}
The impact of global changes on forest ecosystem processes is based on the species-specific responses of trees to the combined effect of multiple stressors and the capacity of each species to acclimate and cope with the environment modification. Combined environmental constraints can severely affect plant and ecological processes involved in plant functionality. This study provides novel insights into the impact of a simultaneous pairing of abiotic stresses (i.e., water and ozone $\left(\mathrm{O}_{3}\right)$ stress) on the responses of oak species. Water stress (using 40 and $100 \%$ of soil water content at field capacity-WS and WW treatments, respectively) and $\mathrm{O}_{3}$ exposure (1.0, 1.2, and 1.4 times the ambient concentration-AA, 1.2AA, and 1.4AA, respectively) were carried out on Quercus robur L., Quercus ilex L., and Quercus pubescens Willd. seedlings, to study physiological traits (1. isotope signature $\left[\delta^{13} \mathrm{C}, \delta^{18} \mathrm{O}\right.$ and $\left.\delta^{15} \mathrm{~N}\right]$, 2. water relation [leaf water potential, leaf water content], 3. leaf gas exchange [light-saturated net photosynthesis, $\mathrm{A}_{\mathrm{sat}}$, and stomatal conductance, $\mathrm{g}_{\mathrm{s}}$ ]) for adaptation strategies in a Free-Air Controlled Exposure (FACE) experiment. Ozone decreased $\mathrm{A}_{\text {sat }}$ in Q. robur and Q. pubescens while water stress decreased it in all three oak species. Ozone did not affect $\delta^{13} \mathrm{C}$, whereas $\delta^{18} \mathrm{O}$ was influenced by $\mathrm{O}_{3}$ especially in $Q$. robur. This may reflect a reduction of $\mathrm{g}_{\mathrm{s}}$ with the concomitant reduction in photosynthetic capacity. However, the effect of elevated $\mathrm{O}_{3}$ on leaf gas exchange as indicated by the combined analysis of stable isotopes was much lower than that of water stress. Water stress was detectable by $\delta^{13} \mathrm{C}$ and by $\delta^{18} \mathrm{O}$ in all three oak species, while $\delta^{15} \mathrm{~N}$ did not define plant response to stress conditions in any species. The $\delta^{13} \mathrm{C}$ signal was correlated to leaf water content (LWC) in Q. robur and Q. ilex, showing isohydric and anisohydric strategy, respectively, at increasing stress intensity (low value of LWC). No interactive effect of water stress and $\mathrm{O}_{3}$ exposure on the isotopic responses was found, suggesting no cross-protection on seasonal carbon assimilation independently on the species adaptation strategy.
\end{abstract}

Keywords: $\delta^{13} \mathrm{C} ; \delta^{18} \mathrm{O} ; \delta^{15} \mathrm{~N}$; ozone; gas exchange; English oak; holm oak; downy oak

\section{Introduction}

Oaks are widely distributed in the Mediterranean basin where drought and air pollution such as tropospheric ozone $\left(\mathrm{O}_{3}\right)$ are the main limiting factors for productivity [1-3]. The diversity of oak species is the result of the adaptation to the environment [4]. A wide phenotypic plasticity helps the 
plants to adapt to chronic environmental stress through the change of morphological and physiological traits [5].

Water shortage affects tree growth through the alteration of metabolism and physiology of primary and secondary meristems [6-8]. Reduced photosynthetic carbon assimilation is often reported as a result of stomatal closure under reduced water availability [9-11]. In contrast, $\mathrm{O}_{3}$ impairs ribulose-1,5-bisphosphate carboxylase/oxygenase (Rubisco) activity and photosynthesis, thus inducing stomatal closure $[12,13]$. Although the individual effects of water deficit and $\mathrm{O}_{3}$ pollution are well documented, the interaction has been less studied. A drought-induced stomatal closure may limit $\mathrm{O}_{3}$ uptake thus reducing $\mathrm{O}_{3}$ injury to plants [14]. However, higher effects of drought were found than long-term $\mathrm{O}_{3}$ exposure in seedlings of $Q$. ilex, where stomata closure induced by drought did not protect from $\mathrm{O}_{3}$ damage [15]. Variations in stable isotope ratios of plant materials allow assessing long-term stress conditions, seasonally, in relation to environmental constraints. Elevated foliar carbon isotope ratio $\left(\delta^{13} \mathrm{C}\right)$ is a proxy of high water use efficiency [16,17]. $\delta^{18} \mathrm{O}$ values are negatively correlated with stomatal conductance $\left(\mathrm{g}_{\mathrm{s}}\right)$ thus reflecting plant water status [18-22]. $\delta^{15} \mathrm{~N}$ significantly decreases as mean annual rainfall increases [23].

Forecasting the impact of global changes on forest ecosystem processes, such as productivity and community composition, is based on the trees' species-specific responses to the combined effect of multiple stressors and the capacity of each species to acclimate and cope with the environmental modification. Therefore, combined constraints are highly relevant in the assessment of tree responses in forest ecosystems. The relationship between physiological responses (photosynthetic and stomatal activity) and stable isotope ratios (carbon, oxygen, and nitrogen) allows identifying distinct phenotypic acclimation strategies.

Among the genus Quercus, a wide range of sensitivity to drought exists [24]. Q. robur, deciduous oak, is considered sensitive to drought and some mortality events were reported in the past following dry seasons [25]. Q. ilex, evergreen oak, avoids desiccation by regulating stomatal conductance in response to the increasing of water deficit intensity [26], making this species highly tolerant to drought and well adapted to Mediterranean environments. The drought tolerance of $Q$. pubescens, deciduous oak, was favored by isohydric stomatal behavior [27] and a less vulnerable hydraulic structure of leaf petioles than $Q$. robur [24]. Deciduous oaks are usually considered more $\mathrm{O}_{3}$-sensitive than evergreen oaks in responses to $\mathrm{O}_{3}$ [28].

The present study aimed to define the responses of $Q$. robur, $Q$. ilex, and Q. pubescens to three levels of $\mathrm{O}_{3}(1.0,1.2$, and 1.4 times the ambient concentration in an open-air facility) and two levels of irrigation (40 and $100 \%$ of soil water content at field capacity) through the stable isotope signatures of $\mathrm{C}, \mathrm{O}$, and $\mathrm{N}$, and gas exchange. The main hypothesis was that oak species respond differently to $\mathrm{O}_{3}$ and irrigation regimes, by regulating photosynthetic rate and stomatal conductance to preserve leaf water potential and content in response to combined stresses. The results of this study provide novel insights into the impact of a simultaneous pairing of abiotic stresses (i.e., water and $\mathrm{O}_{3}$ stress) on the water and carbon responses of oak species in leaves.

\section{Materials and Methods}

\subsection{Plant Material and Experimental Design}

Two-year-old seedlings of potted Q. ilex L., Q. robur L., and Q. pubescens Willd. obtained from nearby nurseries (origins of seedlings: see [29]) were transferred to $10 \mathrm{~L}$ pots in autumn 2014 and then raised at the experimental site in Sesto Fiorentino in central Italy $\left(43^{\circ} 48^{\prime} 59^{\prime \prime} \mathrm{N}, 11^{\circ} 12^{\prime} 01^{\prime \prime} \mathrm{E}, 55 \mathrm{~m}\right.$ a.s.l.), where the experiment was performed from June to October 2015. The seedlings were grown under the combination of three levels of $\mathrm{O}_{3}(1.0,1.2$, and 1.4 times the ambient concentration, denoted as AA, 1.2AA, 1.4AA, respectively) and two levels of water irrigation (100\% and $40 \%$ of soil water content at field capacity, denoted as well-watered, WW, and water-stressed, WS, respectively). During rainfalls, the pots were covered by a plastic cover at $1 \mathrm{~cm}$ above the pot, so that evapotranspiration from the 
soil was not affected (data not shown). The volumetric soil water content (SWC) was measured in the root layer ( $5 \mathrm{~cm}$ depth) by EC-5 soil moisture sensors equipped with an EM5b data logger (Decagon Devices, Pullman WA, USA). In WW plants, SWC was close to field capacity (i.e., $0.295 \mathrm{~m}^{3} \mathrm{~m}^{-3}$ ).

Details on the $\mathrm{O}_{3}$ exposure systems are reported in [30]. In short, $\mathrm{O}_{3}$ was distributed by Teflon tubes hanging down from a fixed grid above the trees. Ozone concentrations at plant height (approx. $1 \mathrm{~m}$ ) were continuously recorded by $\mathrm{O}_{3}$ monitors (Mod. 202, 2B Technologies, Boulder, CO, USA). The daily mean $\mathrm{O}_{3}$ concentrations were $35.1 \pm 1.0 \mathrm{ppb}, 43.0 \pm 1.2 \mathrm{ppb}$, and $49.0 \pm 1.3 \mathrm{ppb}$ in AA, $1.2 \mathrm{AA}$, and 1.4 AA, respectively, over the experimental period [31].

Plots $\left(5 \mathrm{~m} \times 5 \mathrm{~m} \times 2 \mathrm{~m}\right.$ ) were assigned to each $\mathrm{O}_{3}$ treatment in three replicates, with three plants per each combination of species, water regime, and $\mathrm{O}_{3}$ in each plot. The plant position was changed every month within each plot to eliminate positional effects [32].

Other results from the same experiment are available in [31] (risk assessment), [33] (antioxidants), and [29] (belowground responses).

\subsection{Stable Isotopes}

Randomized leaf samples (fully expanded sun-exposed leaves of 4-6th order from the shoot tip) of at least 75-100 mg dry weight (DW) each were gathered at the end of treatments (i.e., on October 15th). Samples were collected from each of the three plants per treatment replicate and joined in a single sample, resulting in three samples for each species per each treatment. Samples were dried and milled in a ball mill.

Stable isotope analyses were performed at the Slovenian Forestry Institute (Ljubljana, Slovenia). An aliquot of each sample $(\mathrm{m}=0.200 \pm 0.050 \mathrm{mg}$ ) was weighed into a tin capsule for $\mathrm{C}$ and $\mathrm{N}$ stable isotope measurements and silver capsule for $\mathrm{O}$ stable isotope measurements using a microanalytical balance Sartorius CPA2P and analyzed with Vario Pyro Cube Elemental Analyzer (Elementar, Germany) coupled with IsoPrime100 Isotope Ratio Mass Spectrometer (IsoPrime, UK).

Both certified reference materials (IAEA-601 and IAEA-602 for oxygen, and USGS40, USGS41, IAEA-N-1, and IAEA-N-2 for carbon and nitrogen) and in-house working standards (acetanilide, benzoide, oak leaves, and cellulose) were used to control the accuracy and precision of the measurements. The analytical precision was $<0.1 \%$ o for carbon and nitrogen, and $<0.3 \%$ o for oxygen, expressed as standard deviation of repeated measurements of in-house working standards $(n=3)$.

Stable isotope results $\left(\delta^{13} \mathrm{C}, \delta^{15} \mathrm{~N}\right.$, and $\left.\delta^{18} \mathrm{O}\right)$ are reported in terms of relative delta $(\delta)$ value as a difference between ${ }^{13} \mathrm{C} /{ }^{12} \mathrm{C},{ }^{15} \mathrm{~N} /{ }^{14} \mathrm{~N}$, or ${ }^{18} \mathrm{O} /{ }^{16} \mathrm{O}$ ratio of the sample and international reference material (Vienna PeeDee Belemnite (VPDB), Atmospheric Nitrogen (AIR), and Vienna Standard Mean Ocean Water (VSMOW)), expressed in per mil (\%o).

\subsection{Leaf Gas Exchange}

Leaf gas exchange was measured in the same fully expanded sun-exposed leaves (4-6th from the shoot tip) of three plants per replicated plot in each treatment using a portable infrared gas analyzer (CIRAS-2 PP Systems, Herts, UK) at controlled values of $\mathrm{CO}_{2}$ concentration (380 ppm), leaf temperature $\left(25^{\circ} \mathrm{C}\right)$, photosynthetic photon flux density (PPFD, $\left.1500 \mu \mathrm{mol} \mathrm{m}{ }^{-2} \mathrm{~s}^{-1}\right)$, and relative humidity $(\mathrm{RH}$, 40-60\%). We determined light-saturated net photosynthetic rate $\left(\mathrm{A}_{\text {sat }}\right)$ and stomatal conductance $\left(\mathrm{g}_{\mathrm{s}}\right)$. Measurements were carried out in two campaigns (June 8-10th and September 27th-October 6th) for all $\mathrm{O}_{3}$ levels (AA, 1.2AA, and 1.4AA) and an additional campaign (August 6-9th) for two $\mathrm{O}_{3}$ levels (AA and 1.4AA) on days with clear sky between 9:00 and 12:00 a.m. CET.

\subsection{Predawn and Midday Leaf Water Potential and Leaf Water Content}

Predawn and midday leaf water potential ( $\Psi_{\text {predawn }}$ and $\Psi_{\text {midday }}$, respectively) were measured on clear-sky days in August with a pressure chamber (PMS Instruments Co., Corvallis, OR, USA) on two to three fully expanded sun-exposed leaves collected from randomly selected shoots $(n=3)$. Midday leaf water potential was measured between 01:00 and 03:00 a.m. CET under PPDF higher than 
$1200 \mu \mathrm{mol} \mathrm{m}{ }^{-2} \mathrm{~s}^{-1}$. Predawn measurements were carried out at $1-2 \mathrm{~h}$ before dawn. The leaf water content (LWC) was obtained through the measurement of fresh leaf weight (FW), then dried at $80^{\circ} \mathrm{C}$ for $72 \mathrm{~h}(\mathrm{DW})$. The leaf water content was calculated as: LWC $(\%)=(\mathrm{FW}-\mathrm{DW}) / \mathrm{FW}$.

\subsection{Statistical Analysis}

The statistical unit was the single plot ( $n=3$ plots). To account for variability in the samples, a pooled standard deviation was computed from the three replicated plots from each species and experimental conditions. Normality of the population distribution was tested using the Shapiro-Wilk test. The homogeneity of variances was performed with the Levene's test. ANOVA analysis was performed to statistically test the effects of treatment (water and ozone), species, month, and their interaction (significance level, $p<0.05$ ). The effect of $\mathrm{O}_{3}$ and water stress on the relationship between $\mathrm{A}_{\text {sat }}$ and $\mathrm{g}_{\mathrm{s}}$ was tested by analysis of covariance (ANCOVA). Post hoc Tukey test was carried out to define the differences among groups. Relationships between $\mathrm{g}_{\mathrm{s}}$ and $\mathrm{A}_{\text {sat }}$, between LWC and $\delta^{13} \mathrm{C}$, between $\mathrm{g}_{\mathrm{s}}$ and $\delta^{18} \mathrm{O}$ were calculated at the species level and tested for significant differences between regression coefficients of water and ozone stress (only significant relationships were shown). Statistical analysis was performed with the OriginPro 8 program (OriginLab Corporation, Northampton, UK).

\section{Results}

The seasonal course of $\mathrm{A}_{\text {sat }}$ and $\mathrm{g}_{\mathrm{s}}$ differed significantly from June to September-October in each species, with higher values in early summer than in autumn in the deciduous oaks (Figure 1 ). $\delta^{13} \mathrm{C}$, $\delta^{18} \mathrm{O}$, and $\delta^{15} \mathrm{~N}$ were statistically different among species (Table 1 ), with higher $\delta^{13} \mathrm{C}$ and $\delta^{18} \mathrm{O}$ values in WS than WW plants of $Q$. robur and Q. pubescens (Figure 2). $\delta^{13} \mathrm{C}$ and $\delta^{18} \mathrm{O}$ increased in WS seedlings of all species relative to WW seedlings (Table 1, Figure 2). $\delta^{18} \mathrm{O}$ was significantly affected by ozone (in $Q$. pubescens) and by water stress (in three oak species), while $\delta^{13} \mathrm{C}$ was significantly affected only by water stress (in $Q$. robur). $\delta^{15} \mathrm{~N}$ did not change among treated plants. $Q$. robur showed significant differences of $\delta^{13} \mathrm{C}$ and $\delta^{18} \mathrm{O}$ between WW and WS in 1.2AA- and AA-treated plants, respectively (Table S1). Plants of $Q$. ilex showed differences of $\delta^{18} \mathrm{O}$ between WW and WS AA-treated plants (Table S1). In $Q$. pubescens, $\delta^{18} \mathrm{O}$ was different between WW and WS in all ozone-level-treated plants, as well as between AA and 1.2AA and 1.4AA in WS plants (Table S1).

The combination of species, water, and $\mathrm{O}_{3}$, and of $\mathrm{O}_{3}$ and water stress resulted in significant effects only for $A_{\text {sat }}$ (Table 1 ). $A_{\text {sat }}$ and $g_{s}$ changed between months differently within the three oak species (Figure 1). Light-saturated net photosynthetic rate $\left(\mathrm{A}_{\mathrm{sat}}\right)$ of $Q$. robur decreased with season whereas elevated $\mathrm{O}_{3}$ and drought reduced it in August and September-October; $\mathrm{A}_{\text {sat }}$ of $Q$. ilex did not show a clear seasonal change during the experimental period, whereas it was lower in WS than WW plants in September-October; $A_{\text {sat }}$ of $Q$. pubescens reached lower values in WS plants in August and September-October whereas $\mathrm{O}_{3}$ decreased it in autumn. Stomatal conductance showed lower values in WW + 1.4AA than in WW + AA in August in Q. robur while the WS treatment significantly decreased it in August, although such stomatal closure was not observed in September-October; $g_{s}$ did not show differences between water and ozone plants of $Q$. ilex (Table S2); in Q. pubescens, $\mathrm{g}_{\mathrm{s}}$ was lower in WS than WW leaves in August while $\mathrm{O}_{3}$ did not decrease $\mathrm{g}_{\mathrm{s}}$ in this species. 


\section{$\square$ WW AA $\square$ WW 1.2AA $\square$ WW 1.4AA \\ $\square$ WS AA $\because$ WS 1.2AA $\square$ WS 1.4AA}
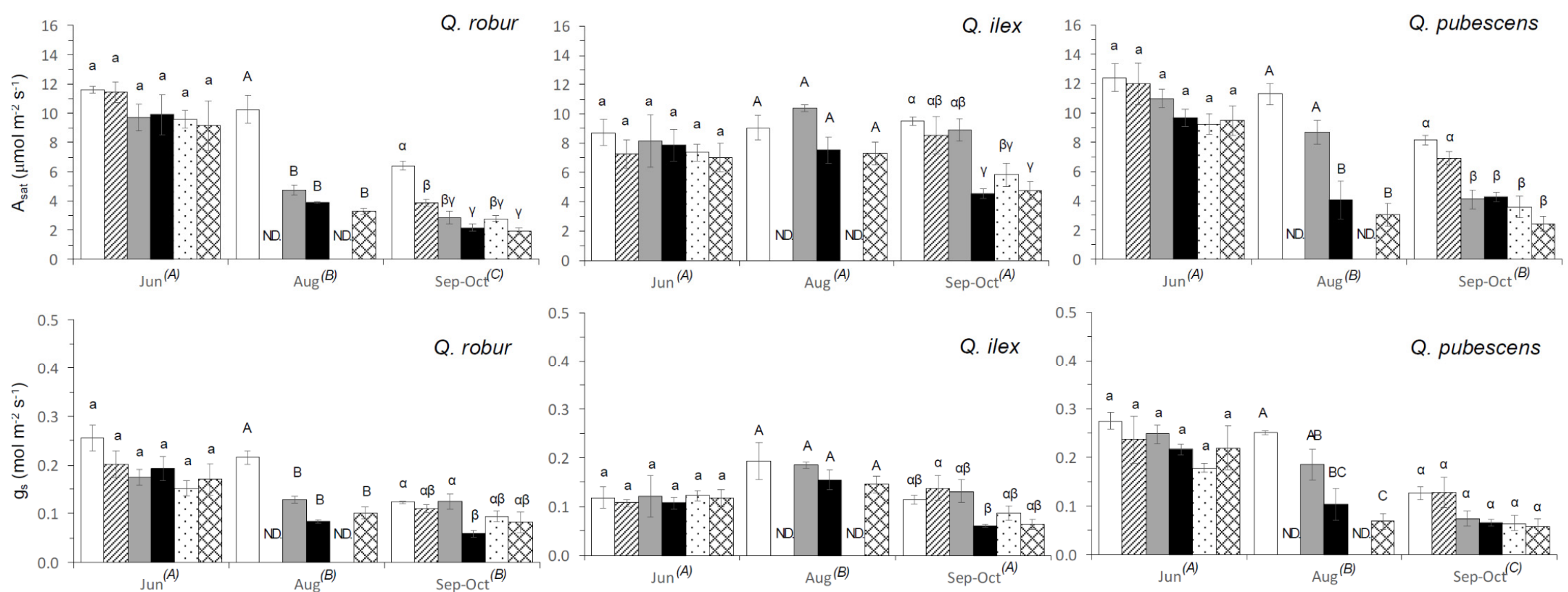

Q. pubescens

Figure 1. Light-saturated net photosynthetic rates $\left(\mathrm{A}_{\mathrm{sat}}\right)$ and stomatal conductance $\left(\mathrm{g}_{\mathrm{s}}\right)$ of leaves of $Q$. robur, $Q$. ilex, and $Q$. pubescens exposed to three levels of $\mathrm{O}_{3}$ (1.0, 1.2 , and 1.4 times the ambient concentration, denoted as AA, 1.2AA, 1.4AA, respectively) and two levels of water irrigation (treatment: WW, $100 \%$ field capacity; WS, $40 \%$ field capacity) in June, August, and September-October. The bars represent mean \pm S.E. ( $n=3$ plots). Different letters show significant differences among treatments $(p<0.05$, Tukey test) within each month for each species. In addition, different capital letters inside parentheses on the $\mathrm{x}$ axis denote significant differences among measured months $(p<0.05$, Tukey test) in each species. N.D. denotes no data available. 

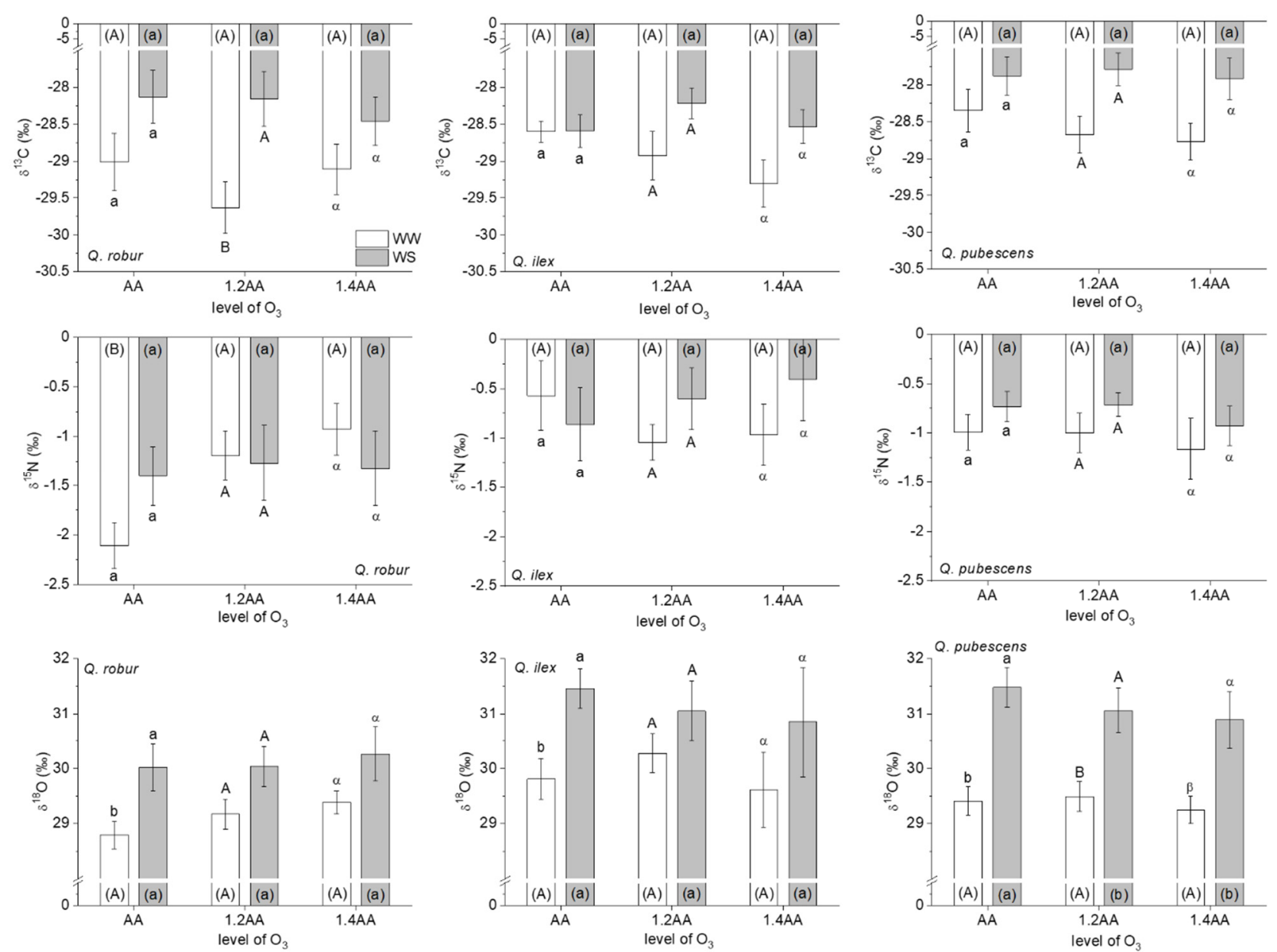

Figure 2. Leaf $\delta^{13} \mathrm{C}, \delta^{18} \mathrm{O}$, and $\delta^{15} \mathrm{~N}$ of $\mathrm{Q}$. robur, $\mathrm{Q}$. ilex, and $\mathrm{Q}$. pubescens exposed to three levels of $\mathrm{O}_{3}(1.0,1.2$, and 1.4 times the ambient concentration, denoted as $\mathrm{AA}$, 1.2AA, 1.4AA, respectively) and two levels of water irrigation (treatment: WW, 100\% field capacity, black squares, solid line; WS, $40 \%$ field capacity, white squares, dashed line). Different letters show significant differences between water levels at same $\mathrm{O}_{3}$ level, different letters inside parentheses show significant differences between ozone levels at same water treatment $(p<0.05$, Tukey test, $n=3$ plots) in each species. 
Table 1. ANOVA of $A_{\text {sat }}$ and $g_{s}$ (four-way analysis), $\delta^{13} \mathrm{C}, \delta^{18} \mathrm{O}$ and $\delta^{15} \mathrm{~N}, \Psi_{\text {predawn }}, \Psi_{\text {midday }}$ and LWC (three-way analysis), of $Q$. robur, Q. ilex, and Q. pubescens exposed to $\mathrm{O}_{3}$ and water treatments is reported ( $p$-level: ${ }^{* * *}, p<0.001 ;{ }^{* *}, p<0.01 ;{ }^{*}, p<0.05 ;$ ns, not significant, $p \geq 0.05$ ).

\begin{tabular}{|c|c|c|c|c|c|c|c|c|}
\hline & \multicolumn{8}{|c|}{$p$-Level } \\
\hline & $\mathbf{A}_{\text {sat }}$ & $\mathrm{g}_{\mathrm{s}}$ & $\delta^{13} \mathrm{C}$ & $\delta^{18} \mathrm{O}$ & $\delta^{15} \mathrm{~N}$ & $\Psi_{\text {predawn }}$ & $\Psi_{\text {midday }}$ & LWC \\
\hline species & $* * *$ & $* *$ & $* * *$ & $* * *$ & $* * *$ & ns & ns & $* * *$ \\
\hline $\mathrm{O}_{3}$ & $* * *$ & * & ns & $* *$ & ns & ns & $*$ & ns \\
\hline water & $* * *$ & $* * *$ & $* * *$ & $* * *$ & ns & $* * *$ & ns & ns \\
\hline species $\mathrm{XO}_{3}$ & $*$ & ns & ns & ns & ns & ns & ns & $* * *$ \\
\hline $\mathrm{O}_{3} \mathrm{X}$ water & * & ns & ns & ns & ns & ns & ns & ns \\
\hline species $X$ water & $* *$ & * & ns & ns & ns & ns & ns & ns \\
\hline species $\mathrm{XO}_{3} \mathrm{X}$ water & $*$ & ns & ns & ns & ns & ns & ns & ns \\
\hline month & $* * *$ & $* * *$ & & & & & & \\
\hline species $X$ month & $* * *$ & $* * *$ & & & & & & \\
\hline month $\mathrm{XO}_{3}$ & ns & * & & & & & & \\
\hline month $X$ water & $* * *$ & $* *$ & & & & & & \\
\hline species $\mathrm{X}$ month $\mathrm{XO}_{3}$ & ns & ns & & & & & & \\
\hline species $\mathrm{X}$ month $\mathrm{X}$ water & $* *$ & ns & & & & & & \\
\hline month $\mathrm{XO}_{3} \mathrm{X}$ water & ns & ns & & & & & & \\
\hline species $\mathrm{X}$ month $\mathrm{XO}_{3} \mathrm{X}$ water & ns & ns & & & & & & \\
\hline
\end{tabular}

Predawn water potential was higher in WW than WS plants of the three oak species (Figure 3; Table S1). Midday water potential of $Q$. ilex reached higher values in 1.2AA plants than AA and 1.4AA plants (Figure 3; Table S1). Q. pubescens showed that $\Psi_{\text {midday }}$ was higher in 1.2AA plants than others, it was different between AA and 1.2AA of WW and WS plants, and between 1.2AA and 1.4AA of WW plants (Figure 3; Table S1). LWC of Q. ilex reached higher values in AA and 1.2AA plants than in 1.4AA (equally in WW and WS) plants (Figure 3); in detail it was different between AA and 1.4AA, and 1.2AA and 1.4AA in both WW- and WS-treated plants (Table S1). In Q. robur, LWC was lower in WS of 1.4AA plants than other conditions (Table S1). LWC of Q. pubescens was lower in WS plants, both 1.2AA and 1.4AA, than WW plants, and differences were found between AA and 1.2AA in WS, and between AA and 1.4AA in WW plants (Figure 3, Table S1).

The slope of the relationship between $A_{\text {sat }}$ and $g_{s}$ was significantly affected by the combined treatments of ozone and water irrigation in the three oak species (Figure 4, Table S3). Water irrigation increased the slope especially in AA for all three species. On the other hand, $1.4 \times \mathrm{AA} \mathrm{O}_{3}$ exposure increased the slope just in WW-treated Q. pubescens leaves.

Significant relationship between LWC and $\delta^{13} C$ was found in $Q$. robur and Q. ilex (Figure 5). $Q$. robur showed a reduction of $\delta^{13} \mathrm{C}$ at increasing LWC, while $Q$. ilex increased $\delta^{13} \mathrm{C}$ at increasing LWC (Figure 5). Q. pubescens did not show relationship between LWC and $\delta^{13} \mathrm{C}$. A significant relationship between $\mathrm{g}_{\mathrm{s}}$ and $\delta^{18} \mathrm{O}$ was found in all species, and did not differ with water and ozone levels (Figure 5). 

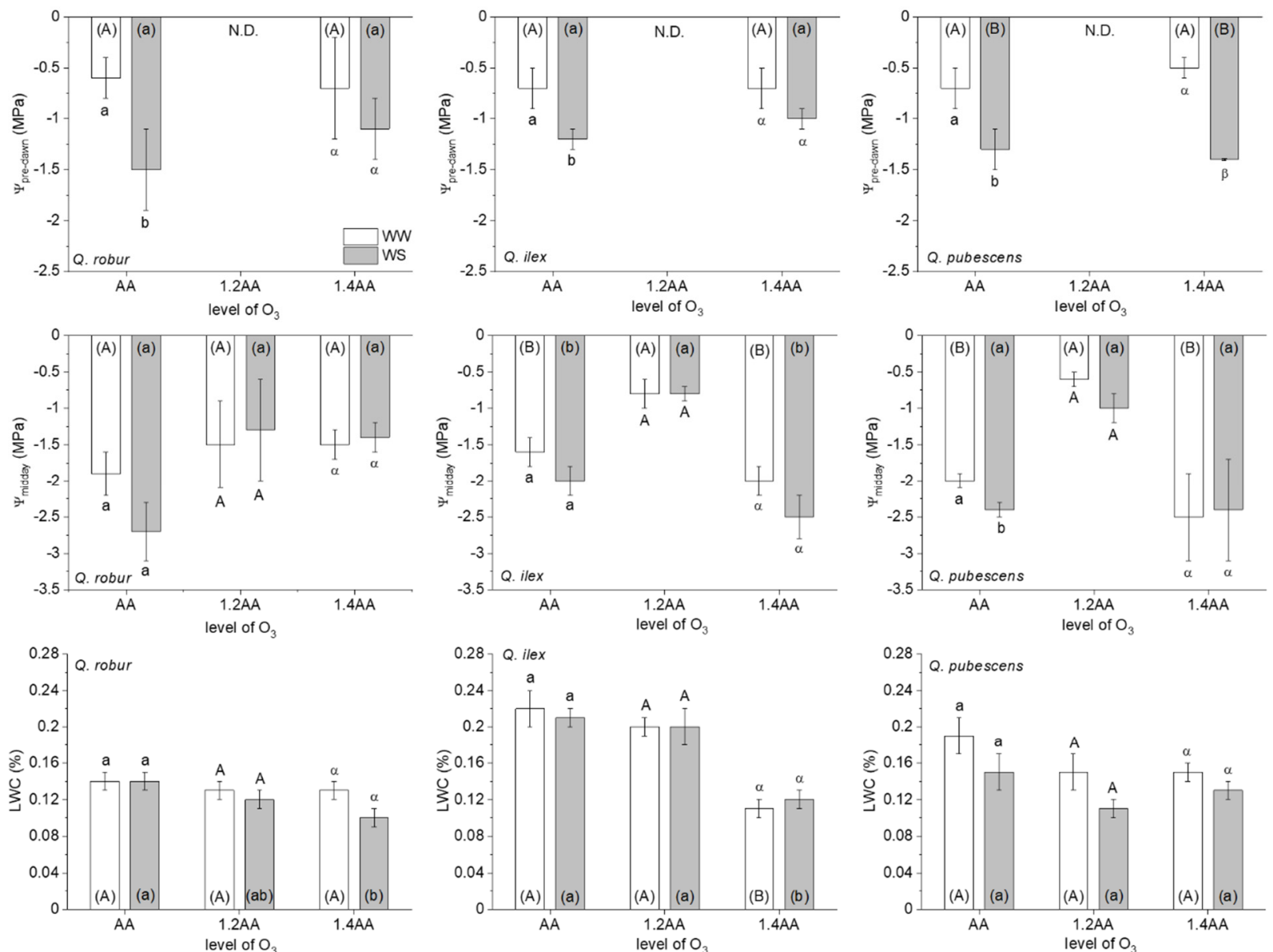

Figure 3. Predawn leaf water potential ( $\left.\Psi_{\text {predawn }}\right)$, midday leaf water potential ( $\Psi_{\text {midday }}$ ), and leaf water content (LWC) of $Q$. robur, $Q$. ilex, and $Q$. pubescens exposed to three levels of $\mathrm{O}_{3}(1.0,1.2$, and 1.4 times the ambient concentration, denoted as AA, 1.2AA, 1.4AA, respectively) and two levels of water irrigation (treatment: WW, $100 \%$ field capacity, white bars; WS, $40 \%$ field capacity, grey bars). Different letters show significant differences between water levels at same $\mathrm{O}_{3}$ level, different letters inside parentheses show significant differences between ozone levels at same water treatment $(p<0.05$, Tukey test, $n=3$ plots) in each species. N.D. denotes no data available. 


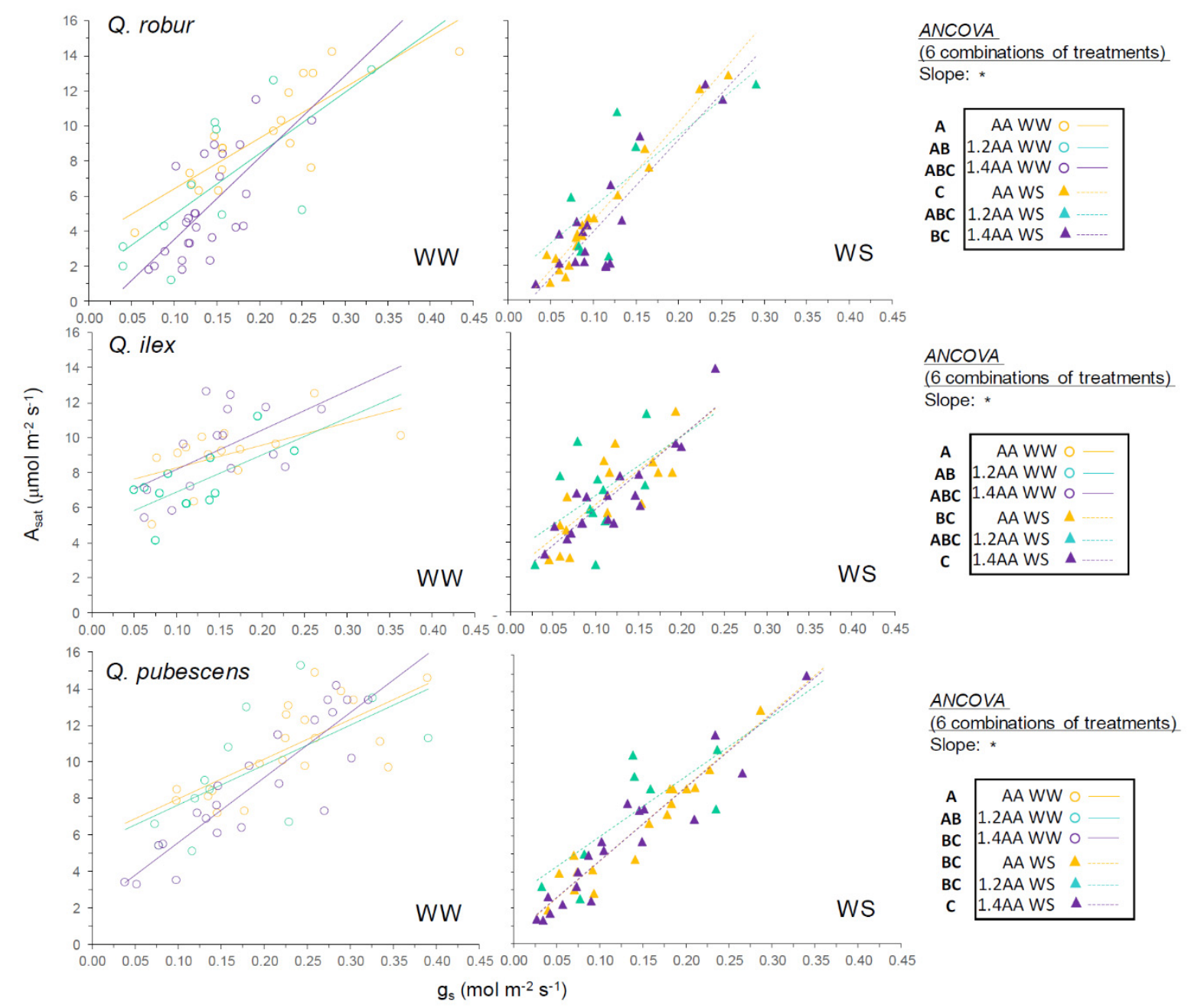

Figure 4. Relationship between light-saturated net photosynthetic rate $\left(\mathrm{A}_{\mathrm{sat}}\right)$ and stomatal conductance $\left(\mathrm{g}_{\mathrm{s}}\right)$ of $Q$. robur, $Q$. ilex, and $Q$. pubescens exposed to three levels of $\mathrm{O}_{3}(1.0,1.2$, and 1.4 times the ambient concentration, denoted as AA, 1.2AA, and 1.4AA, respectively) and two levels of water irrigation (treatment: WW, 100\% field capacity; WS, 40\% field capacity). Pooled data from June to September-October were used. Asterisks show the significance of an ANCOVA: ${ }^{*} p<0.05$. Different capital letters denote significant differences of the slopes among the treatments $(p<0.05)$. All regressions were statistically significant $(p<0.05)$. The values of slope, $\mathrm{y}$-intercept, and determination coefficient $\left(R^{2}\right)$ are listed in Table S3. 

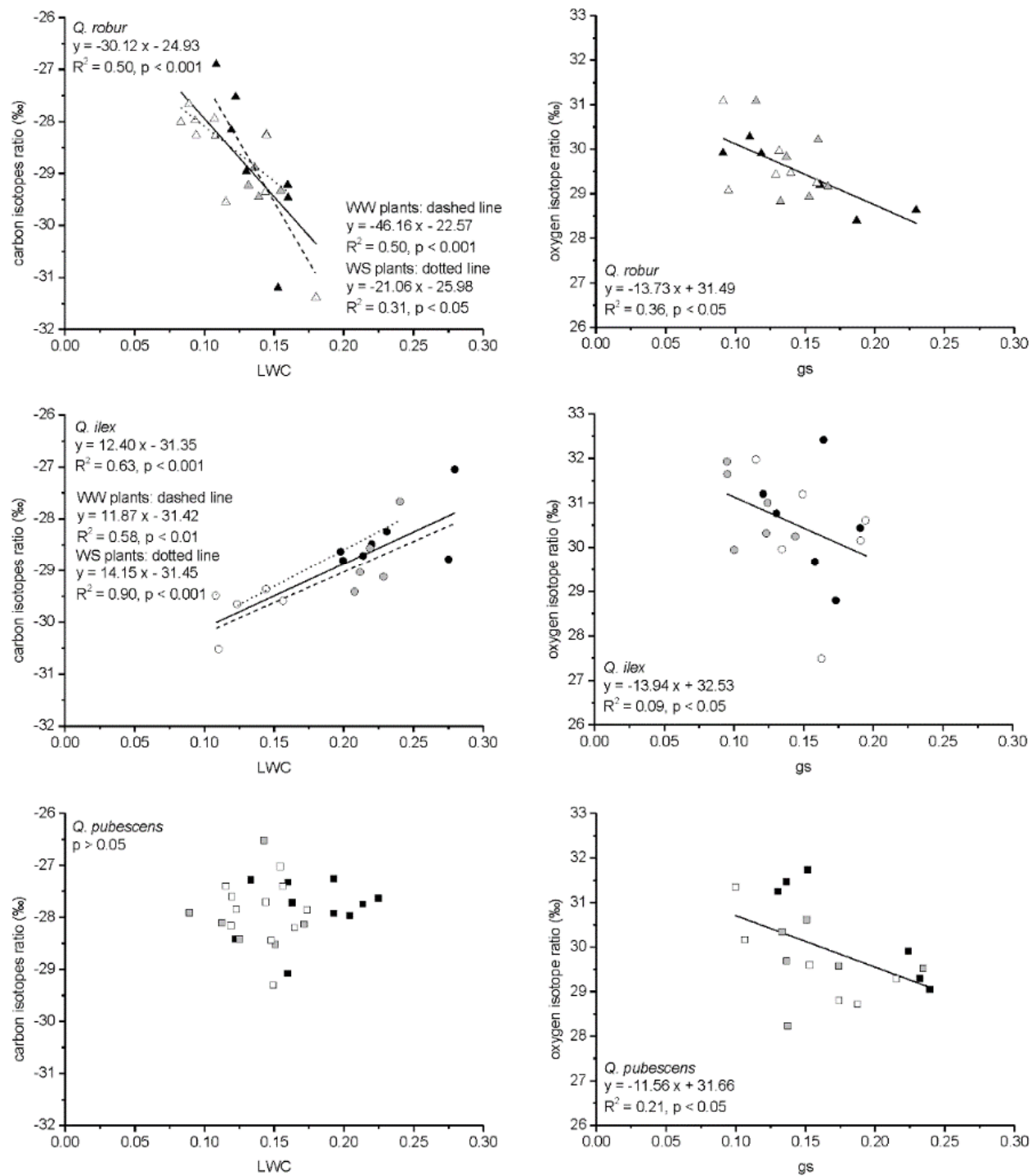

Figure 5. Relationship between leaf water content (LWC) and $\delta^{13} \mathrm{C}(n=3$ plots), and between stomatal conductance $\left(\mathrm{g}_{\mathrm{s}}\right)$ and $\delta^{18} \mathrm{O}$ ( $n=3$ plots) of $Q$. robur (triangles), Q. ilex (circles), and Q. pubescens (squares) exposed to three levels of $\mathrm{O}_{3}(1.0,1.2$, and 1.4 times the ambient concentration, denoted as AA, black symbols; 1.2AA, grey symbols; 1.4AA, white symbols) (regression functions are shown as solid line) and two levels of water irrigation (regression functions of WW plants are dashed line, and WS plants in dotted line) (regression functions are missing when they are not significant).

\section{Discussion}

\subsection{Ozone Effects}

Light-saturated photosynthesis and stomatal conductance differed among oak species (Table 1), showing higher values in the two deciduous species than in the evergreen one (according to [34]), which may result in high stomatal ozone uptake and high ozone damage in deciduous trees [31,35]. Our results confirm that deciduous English oak ( $Q$. robur) is more sensitive to $\mathrm{O}_{3}$ than downy oak (Q.pubescens) and evergreen holm oak $\left(Q\right.$. ilex) [28,31], as $Q$. robur showed lower values of $A_{\text {sat }}$ when exposed to the highest ozone levels (1.4AA). Ozone exposure usually reduces stomatal conductance [36,37] (Figure 1). This was confirmed in $\mathrm{WW} \mathrm{O}_{3}$-exposed Q. robur leaves in August. However, in autumn, even when $\mathrm{A}_{\text {sat }}$ decreased, $\mathrm{g}_{\mathrm{s}}$ remained high in $Q$. robur, implying a less efficient stomatal control after $\mathrm{O}_{3}$ exposure (i.e., stomatal sluggishness) [38-40]. On the other hand, $\mathrm{O}_{3}$ impact on stomatal conductance was not marked in Q. ilex and Q. pubescens throughout the experiment, suggesting a low stomatal reactivity. An 


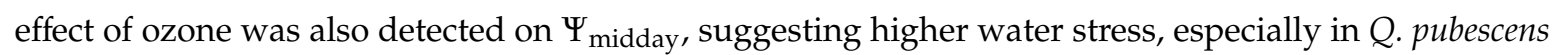
at the 1.2AA ozone level (Figure 3), due to $\mathrm{O}_{3}$ exposure in the daytime at the highest evapotranspiration demand. This response is in contrast with the observed decline of $\mathrm{g}_{\mathrm{s}}$ under $\mathrm{O}_{3}$, but in agreement with stomatal sluggishness (i.e., an imperfect or delayed closure of $\mathrm{O}_{3}$-exposed stomata) [36]. In addition, $\mathrm{O}_{3}$ may modify root anatomy, decreasing the water flux of roots in consequence with the reduced water supply to aboveground parts in the target oak species [29]. Interestingly, the overall effect of $\mathrm{O}_{3}$ on the responses to water deficit was small in the short term (with a slight decline of $g_{s}$ and $\Psi_{\text {midday }}$ ) but significant at the end of the experiment $\left(\delta^{18} \mathrm{O}\right.$ increased), while the overall effect on the carbon balance was highly significant in the short term $\left(\mathrm{A}_{\text {sat }}\right.$ decline) but carbon isotope responses were not significant at the end of the experiment $\left(\delta^{13} \mathrm{C}\right)$. Similar findings were observed in $\mathrm{O}_{3}$-exposed Fagus sylvatica leaves [41,42], highlighting a seasonal variability of $\mathrm{O}_{3}$ effects on $\mathrm{A}_{\text {sat }}$ and $\mathrm{g}_{\mathrm{s}}$. In theory, stomatal closure may lead to a decrease in the intercellular $\mathrm{CO}_{2}$ concentration $\left(\mathrm{C}_{\mathrm{i}}\right)$ [43]. However, this may be compensated by the accompanying decrease in photosynthetic rate due to elevated $\mathrm{O}_{3}$, which results in increases of $C_{i}$ [36]. Even more interestingly, such responses were not species-specific in spite of the different $\mathrm{O}_{3}$ and water deficit sensitivity, suggesting that the three oak species modulated stomatal responses to partly compensate the $\mathrm{O}_{3}$-induced seasonal losses in carbon assimilation.

\subsection{Water Deficit Effects}

The three oak species showed seasonally contrasting patterns in their $\mathrm{A}_{\text {sat }}$ response to water deficit. However, the reduction of photosynthesis of oaks was observed in drought-exposed plants in September-October, highlighting the influence of environmental constraints on tree carbon assimilation [44]. Also, the stomatal conductance was reduced by low water availability in Q. robur and $Q$. pubescens, whereas $g_{s}$ of $Q$. ilex was maintained at the same level from June to September-October. Higher sensitivity of gas exchange to water deficit was observed in deciduous oaks than in the evergreen $Q$. ilex, which is consistent with the previous finding [45]. A significant increase of the slope in the relationship between $A_{\text {sat }}$ and $g_{s}$ across the irrigation regimes was found in three oak species, suggesting an increased intrinsic water use efficiency under water stress conditions (Figure 4). The WS-treated Q. robur leaves had a high slope (Table S3), indicating that water deficit intensively induced stomatal closure in this species, which results in a reduced supply of $\mathrm{CO}_{2}$ to the carboxylation sites $[46,47]$. For all oak species, $\delta^{18} \mathrm{O}$ differed between WW- and WS-treated plants exposed to AA ozone level, resulting in high $\delta^{18} \mathrm{O}$ values from water-limiting conditions, and reduced total canopy transpiration. Water stress generally limits the uptake and transfer of $\mathrm{N}$ into the upper plant parts, resulting in an increased $\delta^{15} \mathrm{~N}$ [48]. However, no response of $\delta^{15} \mathrm{~N}$ in $Q$. ilex and Q. pubescens suggests that the responses of $g_{s}$ were not severe, in contrast with what was observed in crops [49]. However, in Q. robur, $\delta^{15} \mathrm{~N}$ was affected by ozone exposure in well-watered plants (WW), with higher values in 1.2AA and 1.4AA than AA WW plants, indicating a sensitivity to environmental constraints other than growth conditions (Figure 2, Table S1).

\subsection{Combined Responses}

To the best of our knowledge, this is the first study about effects of these combined stressors (namely water deficit and ozone exposure) on isotope signature in the discrimination of adaptation strategies in three species from the same genus (Quercus sp.). Although stable isotope ratios are considered a reliable proxy of plant stress condition and oak species were discriminated on the basis of $\delta^{13} \mathrm{C}$ for water stress, the combination of water and $\mathrm{O}_{3}$ stress did not result in any significant interaction on the isotope signatures. These results confirmed the previous study where the carbon isotopic discrimination was observed in relation to water deficit, but not to ozone in seedlings of Fagus sylvatica, Quercus robur, and an ozone-sensitive Populus clone [50]. The only significant ozone x water interaction was on the responses of $\mathrm{A}_{\text {sat }}$. It has been reported that fast-growing plant species, namely poplar, with high water requirements are more susceptible to ozone and drought stress [50]. In midsummer and autumn, water stress and $\mathrm{O}_{3}$ negatively affected $\mathrm{A}_{\text {sat }}$ in $Q$. robur (Figure 1 ). On the other hand, $\mathrm{A}_{\text {sat }}$ 
of $Q$. pubescens was reduced by ozone and by water treatment, although water stress had stronger negative effects than ozone stress (Figure 1). The photosynthetic rate of $Q$. ilex was reduced by water stress in autumn, showing seasonal plasticity (Figure 1). However, drought did not induce decoupling in the oak response of $A_{s a t}$ to $g_{s}$, and minor effects of ozone were observed, suggesting a resistant plant behavior to a changing environment. Such behavior might be a potential mechanism of oak species to adapt to disturbances such as drought and $\mathrm{O}_{3}$.

The isotope signature highlighted an isohydric behavior of $Q$. robur, where $\delta^{13} \mathrm{C}$ and $\delta^{18} \mathrm{O}$ were high in response to water stress (Figure 2; Table S1). In detail, $\delta^{13} \mathrm{C}$ was significantly affected by water stress, while $\delta^{18} \mathrm{O}$ was significantly affected by ozone and by water stress (Figure 2; Table S1). The species showed natively different sensitivity of $\delta^{13} \mathrm{C}$ to LWC in $Q$. robur (negative correlation) and $Q$. ilex (positive correlation) (Figure 5), although it did not show differences in response to water stress and ozone levels of the experiment. Therefore, the $40 \%$ reduction of irrigation in the experiment determined a mild stress to be detectable through LWC, which is representative of realistic field conditions. Overall, $\delta^{13} \mathrm{C}$ decreased under water stress and $\delta^{18} \mathrm{O}$ increased under ozone stress, while $\delta^{15} \mathrm{~N}$ did not respond to water and ozone stress. Q. robur and Q. pubescens exhibited a more "conservative" water use strategy, characterized by tight stomatal control of transpiration in order to maintain high water use efficiency (according to $[50,51]$ ). On the other hand, Q. ilex showed a low variability in stomatal conductance in comparison to the other species, suggesting an anisohydric behavior to maintain stomata open under water deficit [52].

\section{Conclusions}

Responses of photosynthesis to water stress were species-specific, with Q. pubescens and Q. robur more sensitive than $Q$. ilex, suggesting different adaptation strategies of deciduous and evergreen species. Effects of $\mathrm{O}_{3}$ on physiological traits were lower than those induced by water stress. In detail, the significant interactions of plant water status and $\mathrm{O}_{3}$ stress on photosynthesis were as expected, that is, water deficit reduced the negative impacts of $\mathrm{O}_{3}$. Surprisingly, the effect on photosynthesis did not translate into effects on the seasonal carbon assimilation, that is, $\delta^{13} \mathrm{C}$ did not show a significant response to the combination of water and $\mathrm{O}_{3}$ stress, suggesting adaptation strategies to overcome the growing season. However, $\delta^{13} \mathrm{C}, \delta^{18} \mathrm{O}$, and $\delta^{15} \mathrm{~N}$ were different among species, with higher $\delta^{13} \mathrm{C}$ and $\delta^{18} \mathrm{O}$ values in WS than WW plants of $Q$. robur and $Q$. pubescens, whereas $\delta^{15} \mathrm{~N}$ did not change among treated plants. Different acclimation strategies to cope with stress conditions were found, through the different sensitivity of $\delta^{13} \mathrm{C}$ to LWC in $Q$. robur (negative correlation) and $Q$. ilex (positive correlation). However, no significant isotopic responses were found to discriminate combined treatments and to differentiate response strategy across the studied oak seedlings. These results warrant further isotopic studies over longer time periods and wider ranges of plant species, in order to understand the carbon and water responses of vegetation to a changing environment and different levels and combinations of environmental constraints.

Supplementary Materials: The following materials are available online at http://www.mdpi.com/1999-4907/11/8/ 864/s1: Table S1: ANOVA of $\delta^{13} \mathrm{C}, \delta^{18} \mathrm{O}, \delta^{15} \mathrm{~N}, \Psi_{\text {predawn, }} \Psi_{\text {midday, }}$ and LWC (one-way analysis) of $Q$. robur, $Q$. ilex, and $Q$. pubescens exposed to $\mathrm{O}_{3}$ and water treatments; Table S2: ANOVA (three-way analysis) of net photosynthetic rate $\left(\mathrm{A}_{\mathrm{sat}}\right)$ and stomatal conductance $\left(\mathrm{g}_{\mathrm{s}}\right)$ of $Q$. robur, $Q$. ilex, and Q. pubescens exposed to three levels of $\mathrm{O}_{3}$ and two levels of water treatments; Table S3: Summary of regression parameters between light-saturated net photosynthesis and stomatal conductance for three oak species..

Author Contributions: Conceptualization, Y.H. and E.P.; methodology, T.M., S.Z., T.L., H.K.; data curation, Y.H., C.C., A.G.; writing-original draft preparation, Y.H., C.C.; writing-review and editing, Y.H., C.C., E.P., A.G.; project administration, E.P.; funding acquisition, E.P., H.K. (Slovenian part). All authors have read and agreed to the published version of the manuscript.

Funding: This research was financially supported by the FP7 Capacities project EUFORINNO (REGPOT no. 315982) funded by the European Union and Research Programme P4-0107 Forest biology, ecology and technology financed by the Slovenian Research Agency. The ozone FACE facility was supported by the Ente Cassa di Risparmio Firenze. 
Conflicts of Interest: The authors declare no conflict of interest.

\section{References}

1. Paoletti, E. Ozone impacts on forests. CAB Rev. Perspect. Agric. Vet. Sci. Nutr. Nat. Resour. 2007, 2, 068. [CrossRef]

2. Barbeta, A.; Peñuelas, J. Sequence of plant responses to droughts of different timescales: Lessons from holm oak (Quercus ilex) forests. Plant Ecol. Divers. 2016, 9, 321-338. [CrossRef]

3. Grulke, N.E.; Heath, R.L. Ozone effects on plants in natural ecosystems. Plant. Biol. 2020, 22, 12-37. [CrossRef] [PubMed]

4. Kotlarz, J.; Nasiłowska, S.A.; Rotchimmel, K.; Kubiak, K.; Kacprzak, M. Species diversity of oak stands and its significance for drought resistance. Forests 2018, 9, 126. [CrossRef]

5. Nicotra, A.B.; Atkin, O.K.; Bonser, S.P.; Davidson, A.M.; Finnegan, E.J.; Mathesius, U.; Poot, P.; Purugganan, M.D.; Richards, C.L.; Valladares, F.; et al. Plant phenotypic plasticity in a changing climate. Trends Plant Sci. 2010, 15, 684-692. [CrossRef] [PubMed]

6. Traversari, S.; Francini, A.; Traversi, M.L.; Emiliani, G.; Sorce, C.; Sebastiani, L.; Giovannelli, A. Can sugar metabolism in the cambial region explain the water deficit tolerance in poplar? J. Exp. Bot. 2018, 69, 4083-4097. [CrossRef]

7. Tardieu, F.; Reymond, M.; Hamard, H.; Granier, C.; Muller, B. Spatial distributions of expansion rate, cell division rate and cell size in maize leaves: A synthesis of the effects of soil water status, evaporative demand and temperature. J. Exp. Bot. 2000, 51, 1505-1514. [CrossRef]

8. Tardieu, F.; Granier, C.H.; Muller, B. Water deficit and growth. Coordinating processes without an orchestrator? Curr. Opin. Plant Biol. 2011, 14, 283-289. [CrossRef]

9. Buckley, T.N. How do stomata respond to water status? New Phytol. 2019, 224, 21-36. [CrossRef]

10. Farquhar, G.D.; O'Leary, M.H.; Berry, J.A. On the relationship between carbon isotope discrimination and the intercellular carbon dioxide concentration in leaves. Aust. J. Plant Physiol. 1982, 9, 121-137. [CrossRef]

11. Tcherkez, G. Natural $15 \mathrm{~N} / 14 \mathrm{~N}$ isotope composition in C3 leaves: Are enzymatic isotope effects informative for predicting the 15N-abundance in key metabolites? Funct. Plant Biol. 2011, 38, 1-12. [CrossRef] [PubMed]

12. Kohno, Y.; Matsumura, H.; Ishii, T.; Izuta, T. Establishing critical levels of air pollutants for protecting East Asian vegetation-A challenge. In Plant Responses to Air Pollution and Global Change; Omasa, K., Nouchi, I., De Kok, L.J., Eds.; Springer: Tokyo, Japan, 2005; pp. 243-250.

13. Hoshika, Y.; Watanabe, M.; Carrari, E.; Paoletti, E.; Koike, T. Ozone-induced stomatal sluggishness changes stomatal parameters of Jarvis-type model in white birch and deciduous oak. Plant Biol. 2018, 20, 20-28. [CrossRef] [PubMed]

14. Gao, F.; Li, P.; Feng, Z.Z. Interactive effects of ozone and drought stress on plants: A review. Chin. J. Plant Ecol. 2017, 41, 252-268. (In Chinese)

15. Alonso, R.; Elvira, S.; González-Fernández, I.; Calvete, H.; García-Gómez, H.; Bermejo, V. Drought stress does not protect Quercus ilex L. from ozone effects: Results from a comparative study of two subspecies differing in ozone sensitivity. Plant Biol. 2014, 16, 375-384. [CrossRef]

16. Scheidegger, Y.; Saurer, M.; Bahn, M.; Siegwolf, R. Linking stable oxygen and carbon isotopes with stomatal conductance and photosynthetic capacity, a conceptual model. Oecologia 2000, 125, 350-357. [CrossRef]

17. Farquhar, G.D.; Cernusak, L.A.; Barnes, B. Heavy water fractionation during transpiration. Plant Physiol. 2007, 143, 11-18. [CrossRef]

18. Barbour, M.M.; Fischer, R.A.; Sayre, K.D.; Farquhar, G.D. Oxygen isotope ratio of leaf and grain material correlates with stomatal conductance and grain yield in irrigated wheat. Aust. J. Plant Physiol. 2000, 27, 625-637. [CrossRef]

19. Sheshshayee, M.S.; Bindumadhava, H.; Ramesh, R.; Prasad, T.G.; Lakshminarayana, M.R.; Udayakumar, M. Oxygen isotope enrichment (Delta O-18) as a measure of time-averaged transpiration rate. J. Exp. Bot. 2005, 56, 3033-3039. [CrossRef]

20. Barbour, M.M. Stable oxygen isotope composition of plant tissue: A review. Funct. Plant Biol. 2007, 34, 83-94. [CrossRef]

21. Cabrera-Bosquet, L.; Sanchez, C.; Araus, J.L. Oxygen isotope enrichment $\left(\delta^{18} \mathrm{O}\right)$ reflects yield potential and drought resistance in maize. Plant Cell Environ. 2009, 32, 1487-1499. [CrossRef] 
22. Cernusak, L.A.; Winter, K.; Turner, B.L. Physiological and isotopic $\left(\delta^{13} \mathrm{C}\right.$ and $\left.\delta^{18} \mathrm{O}\right)$ responses of three tropical tree species to water and nutrient availability. Plant Cell Environ. 2009, 32, 1441-1455. [CrossRef] [PubMed]

23. Handley, L.L.; Austin, A.T.; Robinson, D.; Scrimgeour, C.M.; Raven, J.A.; Heaton, T.H.E.; Schmidt, S.; Stewart, G.R. The $15 \mathrm{~N}$ natural abundance $\left(\delta^{15} \mathrm{~N}\right)$ of ecosystem samples reflects measures of water availability. Aust. J. Plant Physiol. 1999, 26, 185-199. [CrossRef]

24. Cochard, H.; Bréda, N.; Granier, A.; Aussenac, G. Vulnerability to air embolism of three European oak species (Quercus petraea, Q. pubescens, Q. robur). Ann. Sci. For. 1992, 49, 225-233. [CrossRef]

25. Urli, M.; Lamy, J.P.; Sin, F.; Burlett, R.; Delzon, S.; Porté, A.J. The high vulnerability of Quercus robur to drought at its southern margin paves the way for Quercus ilex. Plant Ecol. 2014, 216, 177-187. [CrossRef]

26. Baquedano, F.J.; Castillo, F. Drought tolerance in the Mediterranean species Quercus coccifera, Quercus ilex, Pinus halepensis, and Juniperus phoenicea. Photosynthetica 2007, 45, 229. [CrossRef]

27. Nardini, A.; Battistuzzo, M.; Savi, T. Shoot desiccation and hydraulic failure in temperate woody angiosperms during an extreme summer drought. Phytologist 2013, 200, 322-329. [CrossRef] [PubMed]

28. Calatayud, V.; Cervero, J.; Calvo, E.; García Breijo, F.J.; Reig Armiñana, J.; Sanz, M. Responses of evergreen and deciduous Quercus species to enhanced ozone levels. Environ. Pollut. 2011, 159, 55-63. [CrossRef]

29. Mrak, T.; Štraus, I.; Grebenc, T.; Gričar, J.; Hoshika, Y.; Carriero, G.; Paoletti, E.; Kraigher, H. Different belowground responses to elevated ozone and soil water deficit in three European oak species (Quercus ilex, Q. pubescens and Q. robur). Sci. Total Environ. 2019, 651, 1310-1320. [CrossRef]

30. Paoletti, E.; Materassi, A.; Fasano, G.; Hoshika, Y.; Carriero, G.; Silaghi, D.; Badea, O. A new-generation 3D ozone FACE (Free Air Controlled Exposure). Sci. Total Environ. 2017, 575, 1407-1414. [CrossRef]

31. Hoshika, Y.; Moura, B.; Paoletti, E. Ozone risk assessment in three oak species as affected by soil water availability. Environ. Sci. Pollut. Res. 2018, 25, 8125-8136. [CrossRef]

32. Potvin, C.; Tardif, S. Sources of variability and experimental designs in growth chambers. Funct. Ecol. 1988, 2, 123-130. [CrossRef]

33. Pellegrini, E.; Hoshika, Y.; Dusart, N.; Cotrozzi, L.; Gérard, J.; Nali, C.; Vaultier, M.-N.; Jolivet, Y.; Lorenzini, G.; Paoletti, E. Antioxidative responses of three oak species under ozone and water stress conditions. Sci. Total Environ. 2019, 647, 390-399. [CrossRef] [PubMed]

34. Reich, P.B.; Ellsworth, D.S.; Walters, M.B.; Vose, J.M.; Gresham, C.; Volin, J.C.; Bowman, W.D. Generality of leaf trait relationships: A test across six biomes. Ecology 1999, 80, 1955-1969. [CrossRef]

35. Feng, Z.Z.; Büker, P.; Pleijel, H.; Emberson, L.; Karlsson, P.E.; Uddling, J. A unifying explanation for variation in ozone sensitivity among woody plants. Glob. Chang. Biol. 2018, 24, 78-84. [CrossRef] [PubMed]

36. Paoletti, E.; Grulke, N.E. Does living in elevated CO2 ameliorate tree response to ozone? A review on stomatal responses. Environ. Pollut. 2005, 137, 483-493. [CrossRef] [PubMed]

37. Li, P.; Feng, Z.Z.; Calatayud, V.; Yuan, X.Y.; Xu, Y.S.; Paoletti, E. A meta-analysis on growth, physiological, and biochemical responses of woody species to ground-level ozone highlights the role of plant functional types. Plant Cell Environ. 2017, 40, 2369-2380. [CrossRef] [PubMed]

38. Paoletti, E. Ozone slows stomatal response to light and leaf wounding in a Mediterranean evergreen broadleaf, Arbutus unedo. Environ. Pollut. 2005, 134, 439-445. [CrossRef]

39. Hoshika, Y.; Katata, G.; Deushi, M.; Watanabe, M.; Koike, T.; Paoletti, E. Ozone-induced stomatal sluggishness changes carbon and water balance of temperate deciduous forests. Nat. Sci. Rep. 2015, 5, 9871. [CrossRef]

40. Hoshika, Y.; De Carlo, A.; Baraldi, R.; Neri, L.; Carrari, E.; Agathokleous, E.; Zhang, L.; Fares, S.; Paoletti, E. Ozone-induced impairment of night-time stomatal closure in $\mathrm{O}_{3}$-sensitive poplar clone is affected by nitrogen but not by phosphorus enrichment. Sci. Total Environ. 2019, 692, 713-722. [CrossRef]

41. Grams, T.E.E.; Kozovits, A.R.; Häberle, K.-H.; Matyssek, R.; Dawson, T.E. Combining $\delta^{13} \mathrm{C}$ and $\delta^{18} \mathrm{O}$ analyses to unravel competition, $\mathrm{CO}_{2}$ and $\mathrm{O}_{3}$ effects on the physiological performance of different-aged trees. Plant Cell Environ. 2007, 30, 1023-1034. [CrossRef]

42. Gessler, A.; Löw, M.; Heerdt, C.; Op De Beeck, M.; Schumacher, J.; Grams, T.E.E.; Bahnweg, G.; Ceulemans, R.; Werner, H.; Matyssek, R.; et al. Within-canopy and ozone fumigation effects on $\delta^{13} \mathrm{C}$ and $\delta^{18} \mathrm{O}$ in adult beech (Fagus sylvatica) trees: Relation to meteorological and gas exchange parameters. Tree Physiol. 2009, 29, 1349-1365. [CrossRef] [PubMed]

43. Larcher, W. Physiological Plant Ecology, 4th ed.; Springer: Berlin, Germany, 2003.

44. Taneda, H.; Tateno, M. Hydraulic conductivity, photosynthesis and leaf water balance in six evergreen woody species from fall to winter. Tree Physiol. 2005, 25, 299-306. [CrossRef] [PubMed] 
45. Cotrozzi, L.; Remorini, D.; Pellegrini, E.; Landi, M.; Massai, R.; Nali, C.; Guidi, L.; Lorenzini, G. Variations in physiological and biochemical traits of oak seedlings grown under drought and ozone stress. Physiol. Plant. 2016, 157, 69-84. [CrossRef] [PubMed]

46. Haworth, M.; Centritto, M.; Giovannelli, A.; Marino, G.; Proietti, N.; Capitani, D.; De Carlo, A.; Loreto, F. Xylem morphology determines the drought response of two Arundo donax ecotypes from contrasting habitats. GCB Bioenergy 2017, 9, 119-131. [CrossRef]

47. Peters, W.; van der Velde, I.R.; van Schaik, E.; Miller, J.B.; Ciais, P.; Duarte, H.F.; van der Laan-Luijkx, I.T.; van der Molen, M.K.; Scholze, M.; Schaefer, K.; et al. Increased water-use efficiency and reduced $\mathrm{CO}_{2}$ uptake by plants during droughts at a continental scale. Nat. Geosci. 2018, 11, 744-748. [CrossRef]

48. Peuke, A.D.; Gessler, A.; Rennenberg, H. The effect of drought on C and N stable isotopes in different fractions of leaves, stems and roots of sensitive and tolerant beech ecotypes. Plant Cell Environ. 2006, 29, 823-835. [CrossRef]

49. Yousfi, S.; Serret, M.D.; Araus, J.L. Shoot $\delta 15 \mathrm{~N}$ gives a better indication than ion concentration or $\delta 13 \mathrm{C}$ of genotypic differences in the response of durum wheat to salinity. Funct. Plant Biol. 2009, 36, 144-155. [CrossRef]

50. Pollastrini, M.; Desotgiu, R.; Cascio, C.; Bussotti, F.; Cherubini, P.; Saurer, M.; Gerosa, G.; Marzuoli, R. Growth and physiological responses to ozone and mild drought stress of tree species with different ecological requirements. Trees 2010, 24, 695-704. [CrossRef]

51. Moreno-Gutiérrez, C.; Dawson, T.E.; Nicolás, E.; Querejeta, J.I. Isotopes reveal contrasting water use strategies among coexisting plant species in a Mediterranean ecosystem. New Phytol. 2012, 196, 489-496. [CrossRef]

52. Klein, $\mathrm{T}$. The variability of stomatal sensitivity to leaf water potential across tree species indicates a continuum between isohydric and anisohydric behaviours. Funct. Ecol. 2014, 28, 1313-1320. [CrossRef]

(C) 2020 by the authors. Licensee MDPI, Basel, Switzerland. This article is an open access article distributed under the terms and conditions of the Creative Commons Attribution (CC BY) license (http://creativecommons.org/licenses/by/4.0/). 